\title{
An Infant with Posterior Fossa Hemangioma with Aortic Stenosis: Case Report and Review of Literature
}

\author{
Senol Yigit Can, $M D^{1 *}$, Daglioglu Ergun, $M D^{1}$, Aydogdu Basaran Ozge, $M D^{2}$ and Belen Deni, $M D^{1}$
}

${ }^{1}$ Department of Neurosurgery, Ankara Bilkent City Hospital, Ankara, Turkey

${ }^{2}$ Department of Pathology, Ankara Bilkent City Hospital, Ankara, Turkey

*Corresponding author: Senol Yigit Can, MD, Department of Neurosurgery, Ankara Bilkent City Hospital, Ankara, Turkey

\begin{abstract}
We presented a unique case of infantile type hemangioma corresponding with aortic stenosis. Therefore, we accepted this case as a PHACES syndrome. This case will be the 4th case of the literature. The most remarkable feature of PHACE syndrome is infantile hemangioma but abnormalities in the arteries which are not obvious on the clinical examination have considerable potential morbidity. We have certain diagnosis with pathology and no conflicts of interest disclosure.
\end{abstract}

\section{Keywords}

Infantile hemangioma, Phaces syndrome, Posterior fossa hemangioma, Aortic stenosis

\begin{abstract}
Abbreviations
COVID-19: Corona virus disease-2019; GLUT-1: Glucose transporter-1; H: Hour; ICU: Intensive care unit; Kg: Kilogram; Mg: Milligram; MRA: Magnetic resonance angiography; MRI: Magnetic resonance imaging; PHACES: PHACE syndrome is an acronym of (Posterior fossa malformations, hemangioma, arterial anomalies, coarctation of aorta/cardiac defects, eye abnormalities); SMA: Smooth muscle actin
\end{abstract}

\section{Introduction}

The most prevalent benign neoplasm of infancy is the infantile hemangioma [1] with an incidence of $5-10 \%$ in pediatric population [2]. These tumors usually do not present with systemic involvement. Primarily located in extracranial locations such as skin, whereas intracranial hemangiomas less frequently observed pathologies. We presented a unique case of posterior fossa hemangioma with aortic stenosis in a one-yearold infant. Including aortic stenosis as an aortic defect with a posterior fossa hemangioma we can count this condition as a PHACE syndrome. The most remarkable feature of PHACE syndrome is infantile hemangioma but abnormalities in the arteries which are not obvious on the clinical examination have considerable potential morbidity [3,4]. PHACE syndrome is an acronym of (Posterior fossa malformations, hemangioma, arterial anomalies, coarctation of aorta/cardiac defects, eye abnormalities). First described in 1978, by Pascual-Castroviejo [5]. In 1996, Frieden, et al. created acronym [6]. Subsequently, sternal malformations were added the acronym and became PHACES [7].

\section{Case Report}

A one-year-old infant as a close follow-up patient of our hospital's pediatric cardiology department with an aortic stenosis planning a balloon-valvuloplasty. He was admitted pediatric emergency service with a 2-day onset of right hemiparesis without any traumatic injury. According to the patient's perinatal and medical history, he was born after 39 weeks pregnancy with a birth weight of $3125 \mathrm{~g}$. There was no positive family history of hemangiomas. On examination, he was awake, alert, positive pupillary reflexes, no facial paresis, with a $4 / 5$ right hemiparesis. Neither syncope nor seizure was happened. The ophthalmological evaluation showed that both eyes were equal in size and eye motility was normal. No any symptoms of acute hydrocephaly and has subfebril fever of $37.8^{\circ} \mathrm{C}$, without neck stiffness.

Blood tests were evaluated, and no pathologic value was seen. Magnetic resonance imaging (MRI) and an-

Citation: Can SY, Ergun D, Ozge AB, Deni B (2021) An Infant with Posterior Fossa Hemangioma with Aortic Stenosis: Case Report and Review of Literature. Neurosurg Cases Rev 4:058. doi. org/10.23937/2643-4474/1710058

Accepted: February 17, 2021; Published: February 19, 2021

Copyright: (C) 2021 Can SY, et al. This is an open-access article distributed under the terms of the Creative Commons Attribution License, which permits unrestricted use, distribution, and reproduction in any medium, provided the original author and source are credited. 

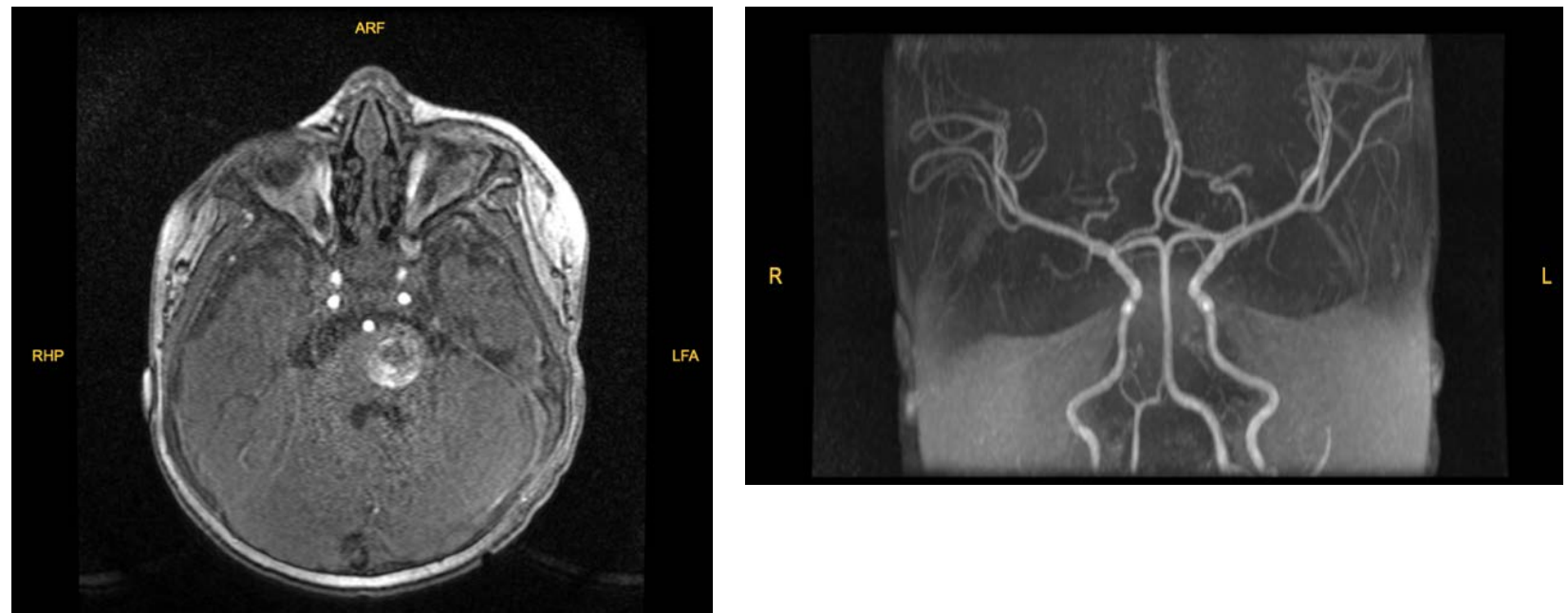

Figure 1: MR angiography showed a non-vascular lesion narrowing forth ventricle on the left part of pons.

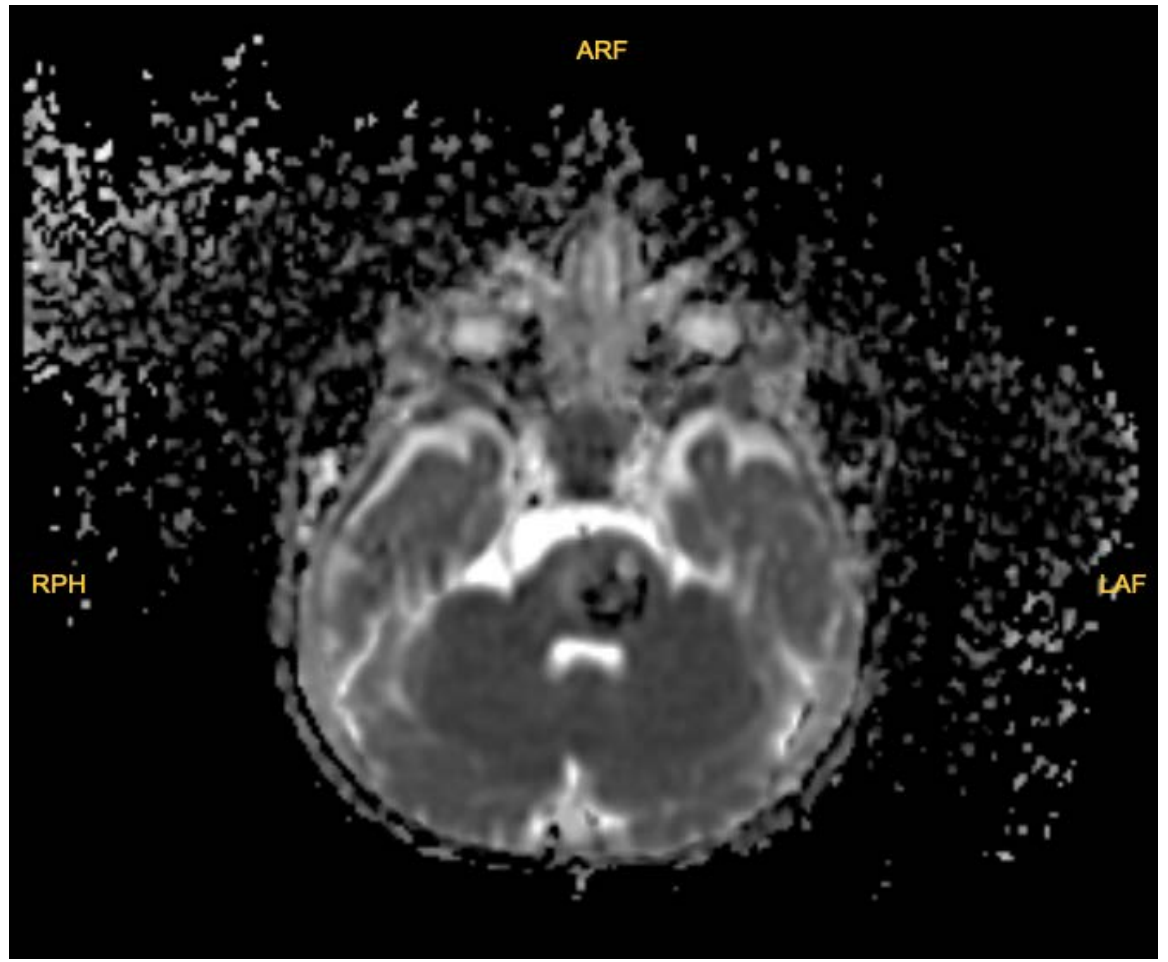

Figure 2: Diffusion sequence of the lesion.

giography (MRA) was obtained which revealed a pontin mass along the dorsal aspect of the posterior fossa. The lesion is heterogeneously hyperintense on T1 and T2 weighted sequences (Figure 1 and Figure 2). The mass was well-circumscribed and heterogeneous, and evidence of previous hemorrhage within it. He was consulted to our department with preliminary diagnosis of pontine cavernoma and hemangioma. The differential diagnoses of an intracranial vascular lesion in this one year-day old infant included hemangioma, hemangioblastoma, vascular malformation, and other neonatal tumor types, such as soft-tissue sarcoma [8].

He was required hospitalization with focal neurologic deficit and admitted to pediatric ICU service to complete preoperative studies. After 12 hours of admission, our team was ready for surgery but on the operation table he has fever of $38.5^{\circ} \mathrm{C}$ anesthesia wanted to exclude COVID-19 infection and sent him back to ICU. Blood cultures and urine cultures were made and nasopharyngeal swab culture for COVID-19 was sent to the public health laboratory of Turkish Health Ministry. Prophylactic antibiotics were started. Tests were revealed after 2 days and showed no infection and his fever was improved. 2 days later we operated patient. A suboccipital craniectomy was performed. The lesion appeared vascular and clearly separated from the normal glial tissue without involvement. Because of the patient's size and the low circulating blood volume, minimizing blood loss was imperative. Blood products were on standby but neither of was used. Hemangioma was gross totally 


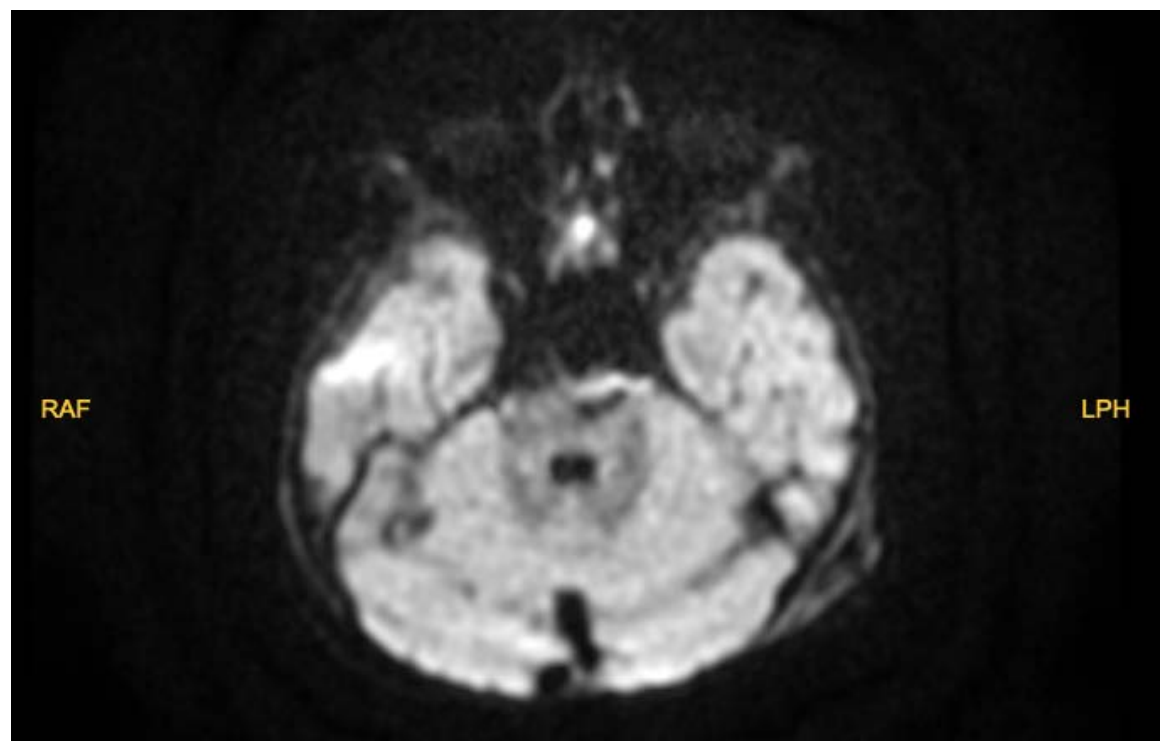

Figure 3: Postoperative 24 hour MRI, no hemorrhage was seen on the MRI.
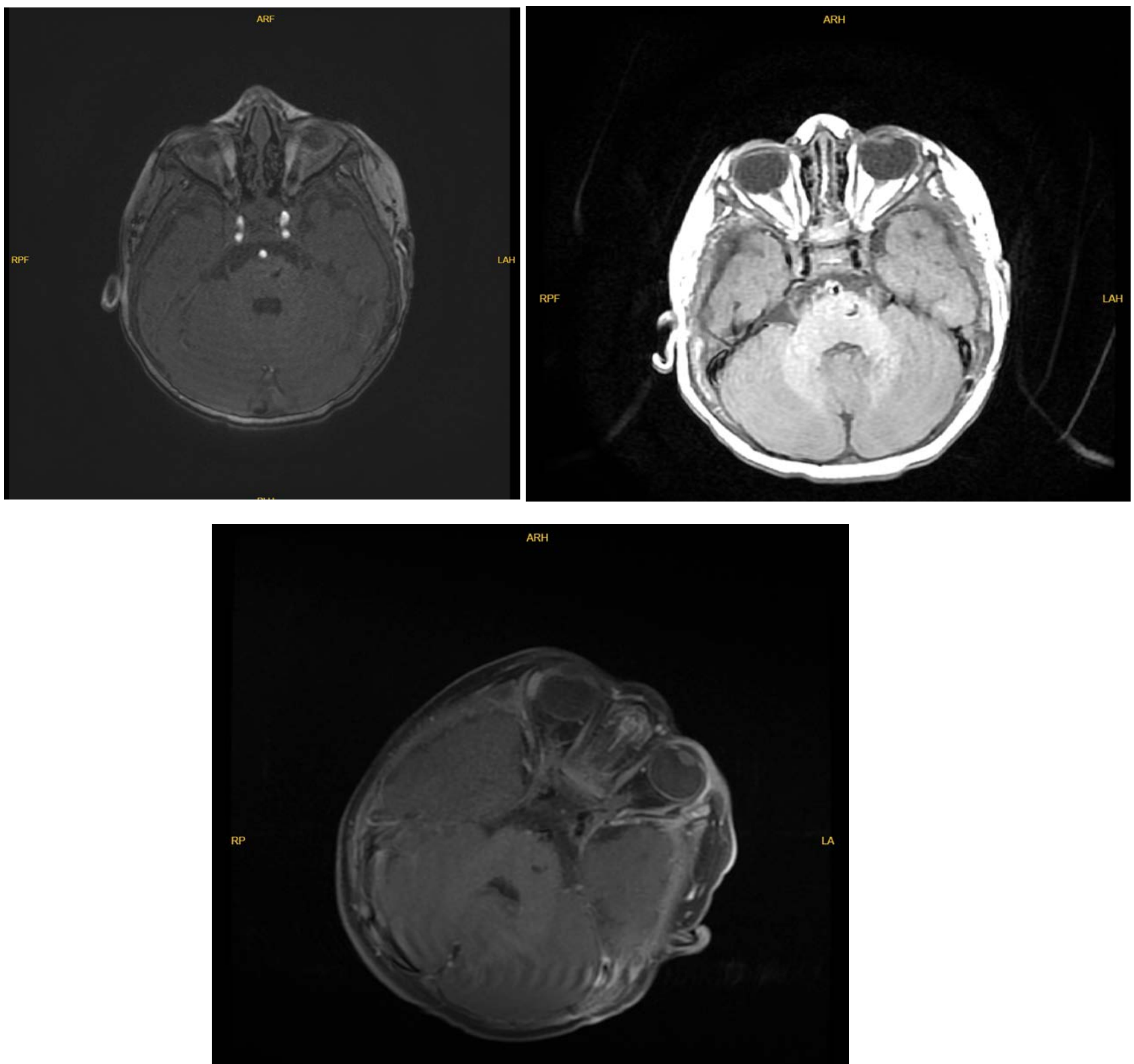

Figure 4: Postoperative Day 30 control MRI, lesion was totally removed. T1, TOF and T2 flair sequences of MRI images. 
resected and no complication was made. After surgery to exclude intracranial hemorrhage, a diffusion MRI was obtained and revealed the lesion was totally resected. No hemorrhage was seen (Figure 3 and Figure 4). On his post-operative day 1 , his hemiparesis was $4+/ 5$ but had a facial paresis so we immediately started $2 \mathrm{mg} /$ $\mathrm{kg} / \mathrm{h}$ prednisolone and continued for 24 hours. In his post-operative day 2 , his facial paralysis was recovered and we stopped prednisolone infusion. He was transferred to infantile service, near his parents. We checked his neurologic examination on our daily routines and his right paresis was totally improved on post-operative day 5 and he discharged with outpatient polyclinic control.

On his post-operative day 12 we took sutures and no cerebral spinal fluid collection was seen. We planned a control magnetic resonance angiography and obtained in his post-operative day 30 (Figure 4). No residue lesion was revealed.

\section{Discussion}

One percent of infantile hemangiomas involve the central nervous system, and approximately half of these are intracranial [8]. Most intracranial infantile hemangiomas classically involve the extra-axial basal cisterns, subarachnoid and ventricular spaces, and cavernous sinus [9]. Our case was demonstrating classically findings of infantile hemangiomas (Figure 5), but confirmation of hemangioma was made by immunohistochemical staining. Pathologic specimen was positive staining with GLUT1 and SMA which are reliable markers for infantile hemangioma. GLUT1 (Figure 6 and Figure 7), a glucose transporter present in normal capillary endothelial

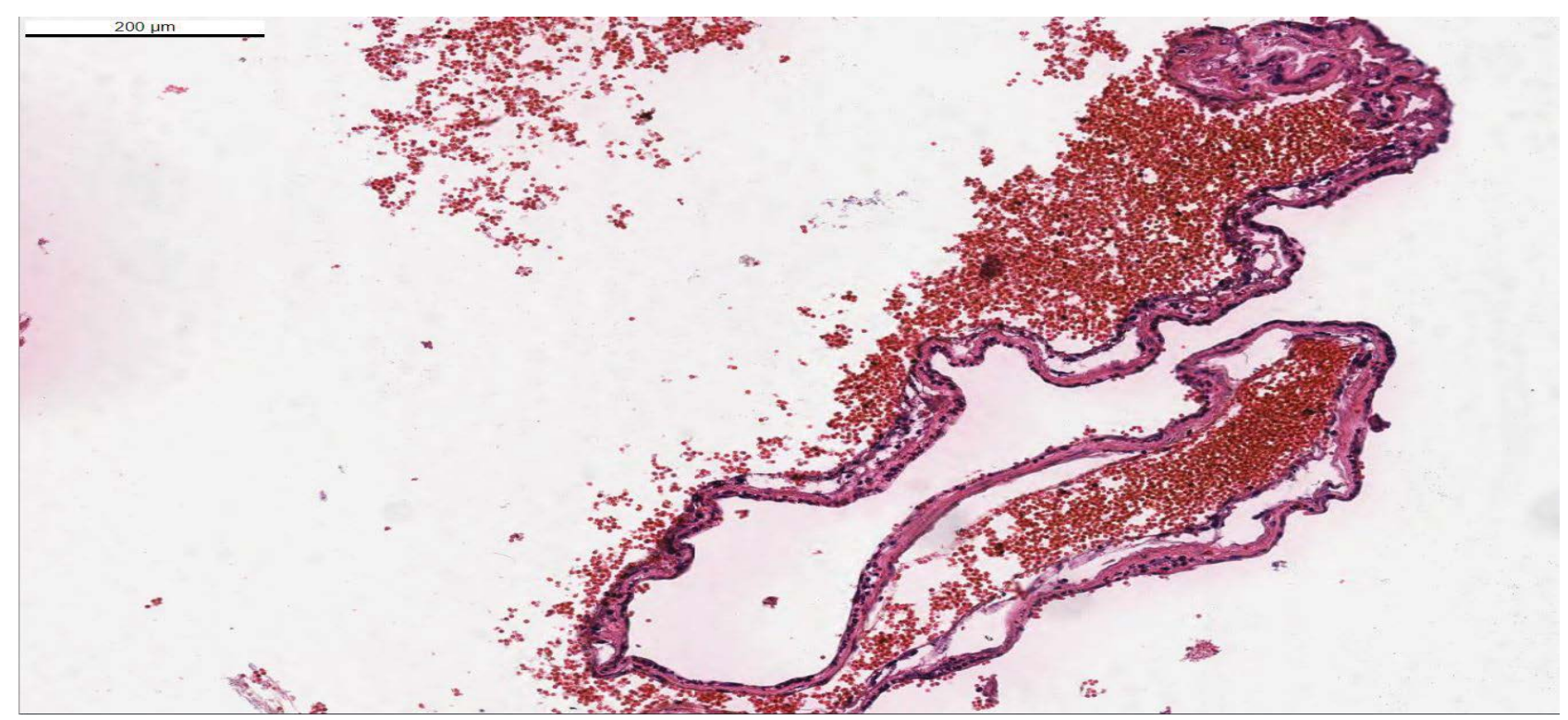

Figure 5: Pathology prepared slides showed congested vascular lesions which has thin walls with hematoxylin eosin dye.

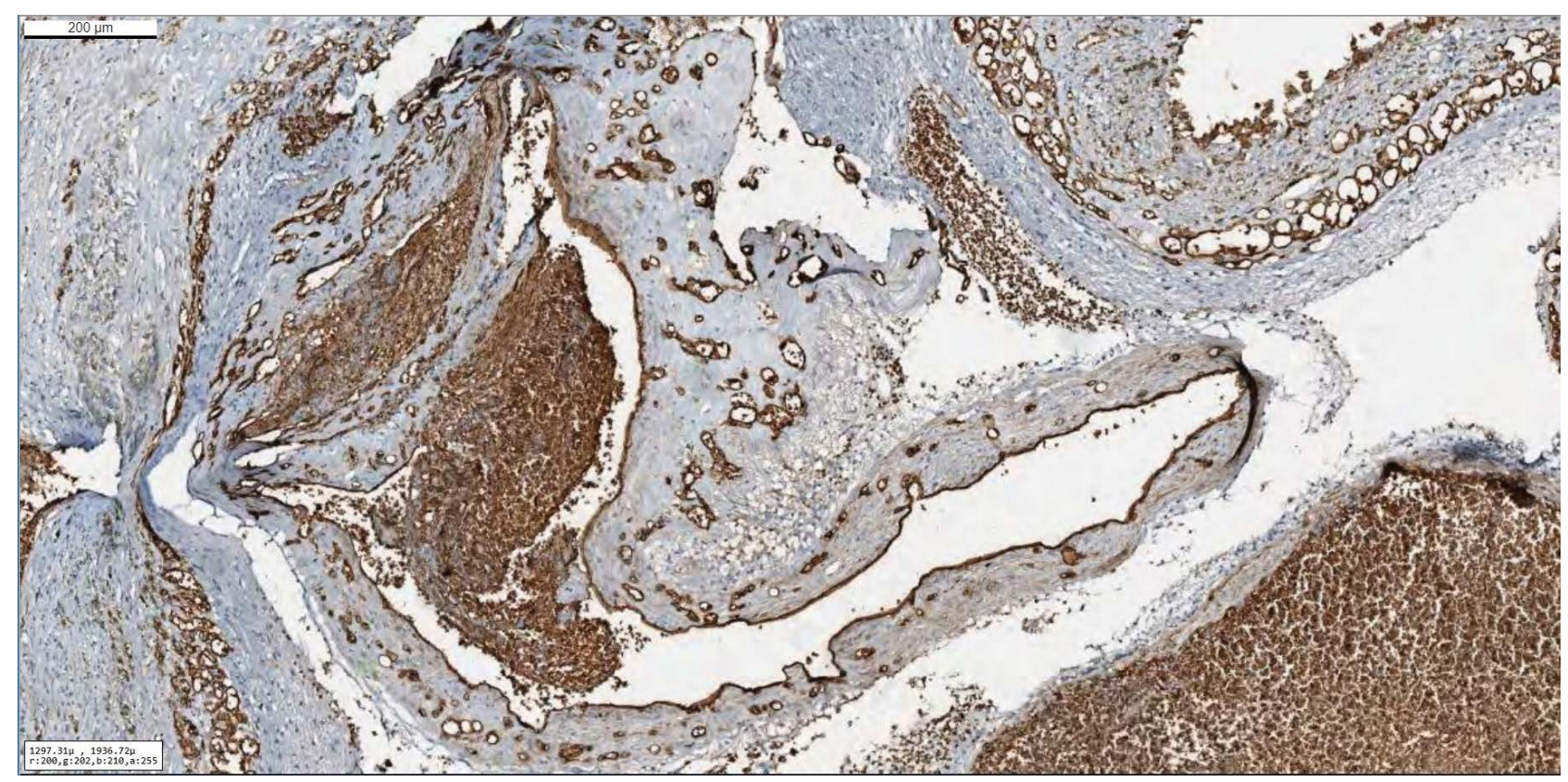

Figure 6: Hematoxylin Eosin dying of the pontine mass. Specimen showed a vascular lesion within slight walls. 


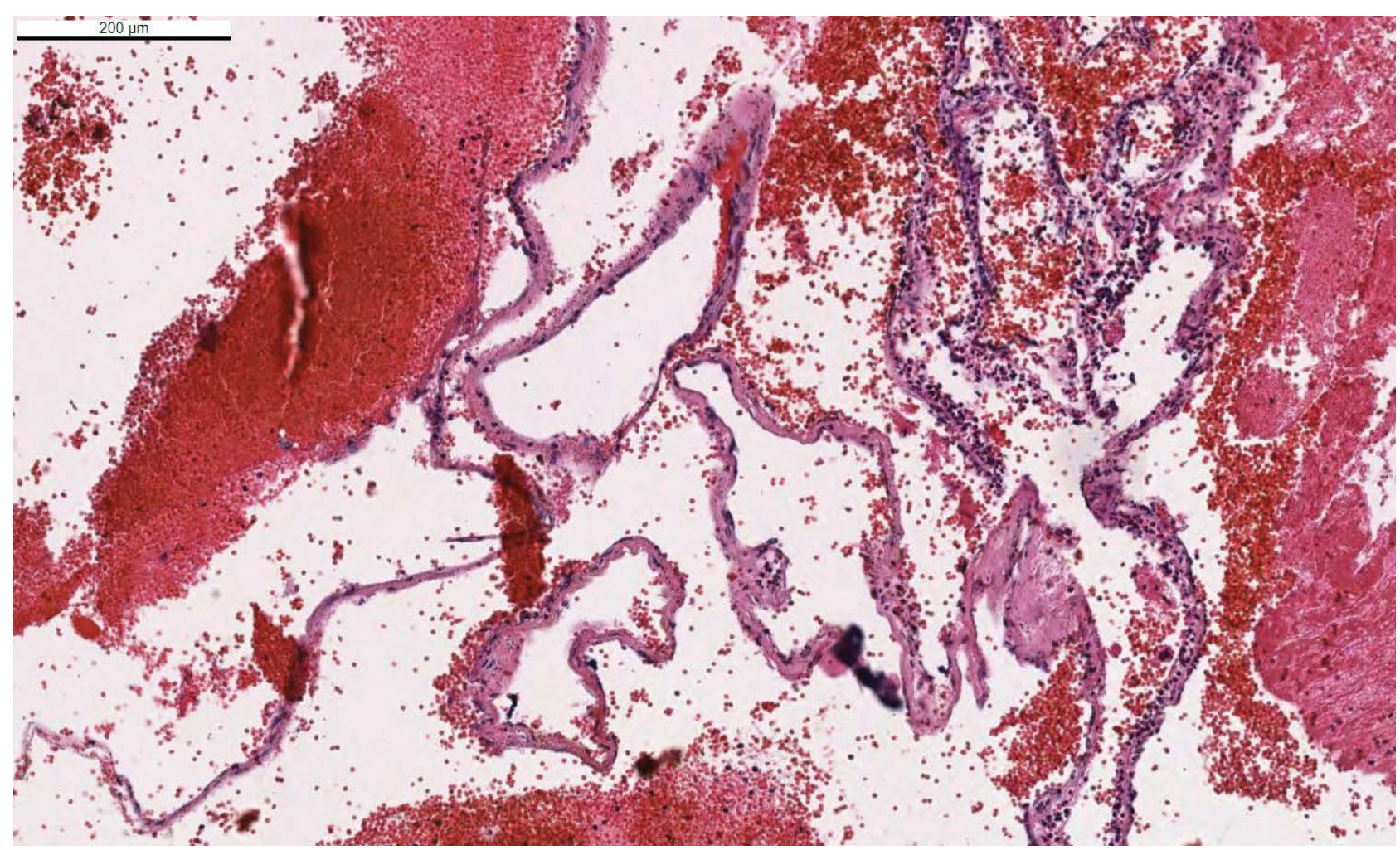

Figure 7: Immunohistochemically, Glut-1 dye showed expressions of the vascular wall and it's compatible with the infantile type hemangioma.

Table 1: Case reports of Dural-based infantile hemangiomas Authors.

\begin{tabular}{|c|c|c|c|c|c|c|}
\hline $\begin{array}{l}\text { Authors, } \\
\text { Year }\end{array}$ & Age, Sex & Presentation & Location & $\begin{array}{l}\text { Diagnosis, } \\
\text { Confirmation }\end{array}$ & Management & Complication \\
\hline $\begin{array}{l}\text { Willing, et } \\
\text { al. [12] }\end{array}$ & 17 Months, Male & $\begin{array}{l}\text { Generalized and Focal } \\
\text { seizures }\end{array}$ & $\begin{array}{l}\text { Right } \\
\text { temporal }\end{array}$ & $\begin{array}{l}\text { Histophathology (No } \\
\text { staining used) }\end{array}$ & Resection & $\begin{array}{l}\text { Postoperative } \\
\text { seizures }\end{array}$ \\
\hline $\begin{array}{l}\text { Philbott, } \\
\text { et al. [9] }\end{array}$ & $\begin{array}{l}12 \text { months, } \\
\text { Female } \\
\text { (Monozygotic } \\
\text { twin) }\end{array}$ & $\begin{array}{l}\text { Enlarged head } \\
\text { circumference }\end{array}$ & Right parietal & $\begin{array}{l}\text { Immunohistochemistry } \\
\text { (GLUT1) }\end{array}$ & Resection & None \\
\hline $\begin{array}{l}\text { Shakir, et } \\
\text { al. [11] }\end{array}$ & $\begin{array}{l}15 \text { days, Female } \\
\text { (Dizygotic twin) }\end{array}$ & $\begin{array}{l}\text { Ventriculomelagaly on } \\
\text { Screening ultarsound }\end{array}$ & $\begin{array}{l}\text { Midline } \\
\text { posterior } \\
\text { fossa }\end{array}$ & $\begin{array}{l}\text { Immunohistochemistry } \\
\text { (GLUT1) }\end{array}$ & Resection & $\begin{array}{l}\text { Postoperative } \\
\text { seizures, } \\
\text { Sinus } \\
\text { thrombosis }\end{array}$ \\
\hline $\begin{array}{l}\text { Belen, et } \\
\text { al. } 2020\end{array}$ & $\begin{array}{l}24 \text { months, Male } \\
\text { (Aortic stenosis, } \\
\text { PHASES) }\end{array}$ & Right hemiparesis & $\begin{array}{l}\text { Midline } \\
\text { posterior } \\
\text { fossa }\end{array}$ & $\begin{array}{l}\text { Immunohistochemistry } \\
\text { (GLUT1) }\end{array}$ & Resection & None \\
\hline
\end{tabular}

cells constituting the blood-brain barrier, is a particularly useful marker of infantile hemangiomas because it differentiates those from other vascular tumors and malformations that have been shown to lack GLUT1 [10]. Several other associated abnormalities have been observed in infants with infantile hemangioma, including arterial anomalies, ipsilateral cerebellar hypoplasia, Dandy-Walker malformation, Moya Moya-like proliferation of the internal carotid artery terminus [11] (Figure 6 and Figure 7).

Despite the benign nature of infantile hemangioma, in our case patient has focal neurologic deficits because of the mass effect. These lesions can cause considerable and permanent injury to the developing brain. Therefore, intervention is required such as these mass effect lesions of infantile hemangiomas. Besides, Propanol is a common treatment protocol of infantile hemangiomas whereas extra-cranial lesions, there is no evidence of using it for intracranial lesions. On the other hand, as a second option of medical therapy steroids were generally use. Mostly using in benign skin lesions with biopsy confirmed. Regression of lesions were reported $[1,8]$. But also no evidence was found in the literature of using steroids for intracranial lesions. Embolization can be a additional therapy to surgical resection. But as an infant patient small vessel can be a handicap to make angiography without complication [11]. 3 of Dural-based infantile hemangiomas were reported in the literature [11]. Our case can be count for the $4^{\text {th }}$ case of literature which was including PHASES symptoms (Table 1) [12]. 


\section{Conflict of Interest}

We have no conflicts of interest to disclose.

\section{References}

1. Daenekindt T, Weyns F, Kho KH, Peuskens D, Engelborghs K, et al. (2008) Giant intracranial capillary hemangioma associated with enlarged head circumference in a newborn. J Neurosurg Pediatr 1: 488-492.

2. Kilcline C, Frieden IJ (2008) Infantile hemangiomas: how common are they? A systematic review of the medical literature. Pediatr Dermatol 25: 168-173.

3. Garzon MC, Epstein LG, Heyer GL, Frommelt PC, Orbach DB, et al. (2016) PHACE Syndrome: Consensus-Derived Diagnosis and Care Recommendations. J Pediatr 178: 2433.

4. Bracken J, Robinson I, Snow A, Watson R, Irvine AD, et al. (2011) PHACE syndrome: MRI of intracerebral vascular anomalies and clinical findings in a series of 12 patients. Pediatr Radiol 41: 1129-1138.

5. Pascual-Castroviejo I (1978) Vascular and nonvascular intracranial malformation associated with external capillary hemangiomas. Neuroradiology 16: 82-84.

6. Frieden IJ, Reese V, Cohen D (1996) PHACE syndrome.
The association of posterior fossa brain malformations, hemangiomas, arterial anomalies, coarctation of the aorta and cardiac defects, and eye abnormalities. Arch Dermatol 132: $307-311$.

7. Metry DW, Dowd CF, Barkovich AJ, Frieden IJ (2001) The many faces of PHACE syndrome. J Pediatr 139: 117-123.

8. Viswanathan V, Smith ER, Mulliken JB, Fishman SJ, Kozakewich HP, et al. (2009) Infantile hemangiomas involving the neuraxis: Clinical and imaging findings. AJNR Am J Neuroradiol.

9. Philpott C, Wray A, MacGregor D, Coleman L (2012) Dural infantile hemangioma masquerading as a skull vault lesion. AJNR Am J Neuroradiol.

10. North PE, Waner M, Mizeracki A, Mrak RE, Nicholas R, et al. (2001) A unique microvascular phenotype shared by juvenile hemangiomas and human placenta. Arch Dermatol 137: $559-570$.

11. Shakir HJ, McBride P, Reynolds RM (2016) Dural-based infantile hemangioma of the posterior fossa: Case report. Surg Neurol Int.

12. Willing SJ, Faye-Petersen O, Aronin P, Faith S (1993) Radiologic-pathologic correlation. Capillary hemangioma of the meninges. AJNR Am J Neuroradiol 14: 529-536. 